\title{
Who is really behind Clinton's AIDS Vaccine crusade?
}

News ANALYSIS If scientists try hard enough they can stop AIDS dead in its tracks within the next ten years by developing a vaccine. That, at least, is clearly the view of US President Bill Clinton, who recently drew widespread media coverage when he used John F. Kennedy's legacy of the Moon landing as the backdrop to announce a new crusade for a vaccine. In a speech at a university graduation, Clinton said a new AIDS Vaccine Research Center would be established at the National Institutes of Health near Washington, DC. The President raised the same issue at the Summit of Industrialized Nations last month in Denver, calling on researchers worldwide to join the crusade.

Some researchers are uneasy about whether HIV can ever be outwitted, and Clinton pledged no new funds for the crusade. The reaction of H.R. Shepherd, head of the Albert Sabin Vaccine Foundation and a fervent believer in an AIDS vaccine, was typical. "Show me the money," he said. Clinton's heart may be in the right place, said Shepherd, but "the White House needs to back it up with concrete action." Not surprisingly, Washington policy observers have taken a similarly dry - and anonymous - view. Some have compared the crusade to a poor man's version of Richard Nixon's War on Cancer, launched in 1971 and, critically, backed by millions of dollars.

However, these reactions may put the AIDS Vaccine Research Center and the President's role in it in too significant a political light. A look at the origins of the idea for the NIH center shows why. The War on Cancer was the brainchild of a handful of oncologists, enthusiastically encouraged by philanthropist Mary Lasker. The research establishment of the day did not endorse the idea and argued that money alone would not cure cancer. By contrast, the NIH AIDS Vaccine Research Center originated within the $\mathrm{NIH}$ itself.

About two years ago, an NIH advisory group chaired by virologist Arnold Levine of Princeton recommended that the then newly established Office of AIDS Research (OAR) put significant effort into vaccine studies, with a particular emphasis on immunology. Shortly after that, another advisory committee, chaired by David Baltimore (of the Massachusetts Institute of Technology), said that the NIH needed to be more flexible in organizing its "inhouse" research programs. From there, ac- cording to NIH director Harold Varmus, came the seeds of the idea to create a vaccine center within the NIH.

William Paul, head of the OAR, proposed organizing a consortium of scientists on campus whose research is pertinent to an AIDS vaccine. Not long after, the White House become peripherally involved. On World AIDS Day last December, Varmus, Paul and Anthony Fauci, the director of the National Institute of Allergy and Infectious Diseases (NIAID) and the NIH's most visible AIDS researcher, were among a small group who met President Clinton and Vice-President Al Gore. Among the topics they covered was the inherent appeal of a prophylactic vaccine. According to one of those present, Clinton seemed to take an interest in the idea. "Things gradually came together," says Paul. The National Cancer Institute agreed to co-sponsor the vaccine center with NIAID. This is a significant symbol of intramural collaboration, which, Paul contends, is more important than money at present in manifesting the NIH's commitment to vaccine research. Paul also wants the center, which may be a "virtual laboratory" without walls, to be highly targeted. "The goal of this is not to write papers but to actually develop a vaccine," he says.

In the 1980s, many scientists despaired of a prophylactic AIDS vaccine. Fauci even admitted publicly that research on the vaccine was stagnant. But during the intervening years, the state of the science has changed. AIDS vaccine researchers are taking heart because of new approaches that rely as much on understanding and modifying the host's immune response to HIV as to modifying or incapacitating the virus. As Paul says, vaccinology and immunology, which parted ways in the 1920 s, are coming back together.

There is also hope that the vaccine center will put the NiH's intramural research programs - currently seen as somewhat weak - back on the intellectual map. If the center can match, in success and visibility, the Human Genome Project, one of the few programs to draw wide acclaim, it will improve the institutes' standing.

Although current NIH funding for AIDS vaccine research of about $\$ 150$ million may be adequate for now, few doubt that when significant progress is made, substantial resources will have to be added to the program. Most agree that there is no point in pouring money in unless the science justifies it, but when it does the money must follow. Perhaps that will be the real challenge for Clinton. He will only be able to claim a vaccine against AIDS as his legacy to science if his Administration backs up its dreams with hard cash.

BARBARA J.CULLITON

\section{MRC shake up}

In a bid to get the highest returns on its investment, Britain's Medical Research Council has introduced a radical overhaul of its grants system. The council is to phase out threeyear project grants to individual researchers, and instead put money into cooperative grants that bring a "critical mass" of scientists in separate but related disciplines together.

George Radda, the MRC's chief executive, said the reforms were a means of "backing the best teams in the best places," suggesting that health problems were most likely to be solved by multidisciplinary teams." "This is the way we believe science should go in the future," he said. The reforms will affect half of the council's total budget of $£ 300$ million ( $\$ 480$ million).
Five types of grant are planned:

-Up to 20 large "center grants" awarded to units with an internationally recognised director, in partnership with a university.

- Up to 80 cooperative group grants requiring at least three individuals

- Up to 30 development COPYRIGHT REASONS grants to universities that lack the infrastructure required to apply for cooperative group grants.

- Young scientists will be supported with up to 120 career establishment grants.

- To encourage risk-taking, $£, 800,000$ a year is earmarked

for innovation awards.

In general, the universities have welcomed the changes.

PHYLLIDA BROWN London 